\title{
Eklampsia dan Sindroma HELLP pada Kehamilan Awal: Penegakan Diagnosis dan Manajemen Anestesia
}

\author{
Fahmi Agnesha, Sri Rahardjo \\ Departemen Anestesiologi dan Terapi Intensif Fakultas Kedokteran, Kesehatan Masyarakat dan Keperawatan \\ Universitas Gadjah Mada Yogyakarta
}

\begin{abstract}
Abstrak
Preeklampsia merupakan salah satu penyebab morbiditas dan mortalitas ibu hingga saat ini. Penyakit ini memiliki beberapa bentuk manifestasi klinis yang merupakan gambaran dari perburukan dari preeklampsia diantaranya adalah eklampsia dan sindroma HELLP (hemolysis, elevated liver enzyme dan low platelet). Kedua perburukan preeklampsia tersebut biasa terjadi pada usia kehamilan 27 hingga 37 minggu, namun semakin dini onset penyakit ini muncul prognosis bagi ibu akan semakin buruk. Seorang perempuan usia 34 tahun, gravida 3 paritas 1 abortus 1 hamil 24 minggu, janin intra uterine fetal death. Pasien datang dikarenakan kejang seluruh badan selama 5 menit sekitar 30 menit yang lalu sebelum masuk rumah sakit. Berdasarkan pemeriksaan fisik didapatkan hipertensi dengan tekanan darah 180/110 mmHg. Selain itu dari pemeriksaan penunjang didapatkan trombositopenia 94.000, SGOT $350 \mathrm{IU} / \mathrm{L}$ and SGPT $285 \mathrm{IU} / \mathrm{L}$. Pasien didiagnosis dengan eklampsia dan sindroma HELLP, kemudian dilakukan terminasi kehamilan melalui seksio sesarea darurat dengan anestesia umum. Pembahasan: manajemen anestesia pada ibu hamil dengan eklampsia dan sindroma HELLP memiliki beberapa pertimbangan khusus antara lain adanya kesulitan intubasi, kemungkinan terjadinya peningkatan tekanan intrakranial dan juga efek pemberian anti kejang terhadap kontraksi rahim. Melalui penegakan diagnosis dan pengenalan risiko yang mungkin dapat terjadi pada pasien dengan eklampsia dan sindroma HELLP dapat direncanakan tindakan dan manajemen anestesia yang lebih baik sehingga morbiditas dan mortalitas ibu dengan eklampsia dan sindroma HELLP dapat diturunkan.
\end{abstract}

Kata kunci: eklampsia; manajemen anestesia; sindroma HELLP

\section{Eclampsia and HELLP Syndrome in Early Pregnancy: Diagnosis and Management of Anesthesia}

\begin{abstract}
Preeclampsia is one of the leading cause maternal morbidity and mortality. It has various clinical manifestations that describe the severity of the disease include eclampsia and HELLP syndrome (hemolysis, elevated liver enzyme dan low platelet). Those worsening of preeclampsia usually happen during 27 to 37 weeks of gestation. Even though the earlier the onset showed the worse the prognosis is. A pregnant woman 34 years old, gravidy 3 parity 1 abortus 1, 24 weeks gestational age with intra uterine fetal death. Patient had chief complain for seizure before admission. From the physical examination found that patient has severe hypertension with blood pressure 180/110 mmHg. The laboratory result showed trombositopenia 94.000, SGOT 350 IU/L and SGPT 285 IU/L. Patient diagnosed with eclampsia and HELLP syndrome and then did emergency caesarean section with general anesthesia. Discussion: The anesthesia management in this case should be specifics due to the patient condition circumstances with eclampsia and HELLP syndrome. We should prepare for difficult airway, intracranial pressure increase and effect of anticonvulsant agent to the uterine tone. By diagnose and identify the risk of eclamptic and HELLP syndrome patient carefully we can plan the better procedure and anesthesia management that maternal morbidity and mortality can be reduced.
\end{abstract}

Key words: anesthesia management; eclampsia, HELLP syndrome 


\section{Pendahuluan}

Eklampsia merupakan bentuk klinis terburuk dari preeklampsia. Eklamsia ialah perburukan dari preeklamsia yang ditandai oleh kejang tonik-klonik yang disertai hipertensi, dan tidak disebabkan oleh kelainan sistemik lainnya, seperti epilepsi, ensefalitis, kelainan elektrolit. ${ }^{1-4}$ Preeklamsia dan eklamsia merupakan salah satu penyebab kematian terbesar seorang ibu hamil di Indonesia. Diagnosis dan penatalaksanaan preeklamsia dan eklamsia sangat penting untuk diketahui dan dijalankan dalam upaya kita menurunkan angka kematian ibu di Indonesia. ${ }^{5}$

Estimasi WHO, angka kejadian preeklamsia di negara berkembang berkisar antara 1,8-16,7 \%. ${ }^{4}$ Di Indonesia angka kejadian preeklamsia berkisar antara 3-10\%.5 Di Rumah Sakit Cipto Mangunkusumo (RSCM) 95\% dari kasus hipertensi pada kehamilan adalah preeklamsia, $58,1 \%$ digolongkan sebagai hipertensi awitan dini. ${ }^{5}$ Preeklamsia merupakan suatu sindroma pada kehamilan yang tidak hanya ditandai oleh hipertensi, namun mempengaruhi seluruh sistem organ pada tubuh ibu. ${ }^{6}$ Selain ditandai dengan hipertensi, preeklamsia juga harus disertai penanda perburukan dari satu atau lebih organ pada ibu hamil, misalkan peningkatan transaminase, penurunan fungsi ginjal, keluhankeluhan seperti nyeri kepala, penglihatan buram, dan lain-lain. Pada konsensus terkini, diagnosis preeklamsia tidak mutlak harus disertai dengan pertanda proteinuria. ${ }^{7}$

Selain eklampsia, preeklampsia dapat berkembang menjadi sindroma HELLP. Istilah sindroma HELLP pertama kali diperkenalkan. Tahun 1982, yang merupakan sebuah akronim untuk menjelaskan kondisi klinis berupa hemolysis, elevated liver enzyme dan low platelet. ${ }^{8}$ Sindroma ini memiliki angka kejadian sekitar $0.5-0.9 \%$ kehamilan dan biasanya bermanifestasi pada usia kehamilan antara 27 hingga 37 minggu. Sekitar $30 \%$ kasus terjadi setelah persalinan. ${ }^{9}$ Walaupun secara etiopatogenesis masih belum jelas, secara histopatologis ditemukan deposit fibrin intravaskuler pada hati yang kemungkinan diduga mengakibatkan obstruksi hepatik sinusoidal, kongesti vaskuler intrahepatik dan peningkatan tekanan intrahepatik yang mengakibatkan nekrosis hepatik, perdarahan intraparenkimal dan subcapsular kemudian mengakibatkan ruptur hepar. ${ }^{10}$ Gejala klinis tipikal dari sindroma HELLP adalah adanya nyeri pada abdomen kuadran kanan atas atau nyeri epigastrik, mual dan muntah. Namun demikian, sindroma ini dapat muncul tanpa gejala yang spesifik dan diagnosis menjadi sulit ditegakkan. ${ }^{11}$

\section{Kasus}

Pasien seorang wanita,usia 34 tahun, gravida 3 paritas 1 abortus 1 hamil 24 minggu, janin intra uterine fetal death. Pasien datang dikarenakan kejang seluruh badan selama 5 menit sekitar 30 menit yang lalu sebelum masuk rumah sakit. Pasien selama ini kontrol antenatal rutin di bidan. Satu hari sebelum masuk rumah sakit pasien mengeluh nyeri ulu hati lalu periksa ke bidan dan diberikan obat maag. Tiga puluh menit sebelum masuk rumah sakit pasien kejang dan di rumah sakit pasien kejang selama 3 menit.

Berdasarkan pemeriksaan fisik didapatkan kesadaran glasgow coma scale(GCS) 14E3M6V5, jalan nafas bebas, frekuensi nafas 30 kali per menit, tekanan darah $180 / 110 \mathrm{mmHg}$, nadi 130 kali per menit, suhu $37,2^{\circ} \mathrm{C}$. Pasien berat badan 68 $\mathrm{kg}$, tinggi $165 \mathrm{~cm}$, IMT 24,9 kg/m². Pemeriksaan status generalis menunjukkan konjungtiva tidak anemis, sklera ikterik, mallampati II serta jantung, paru-paru, dan vertebra tidak terdapat kelainan. Pada pemeriksaan abdomen denyut jantung janin tidak ditemukan. Pasien dilakukan pemasangan kateter dan didapatkan urin keluar kurang lebih $300 \mathrm{cc}$ gross hematuria.

Hasil laboratorium didapatkan kadar hemoglobin $14.1 \mathrm{gr} \%$, hematokrit $40.9 \%$, leukosit $24.000 \mathrm{mg} /$ $\mathrm{dL}$, trombosit $94.000 \mathrm{mg} / \mathrm{dL}$, GDS $121 \mathrm{mg} / \mathrm{dL}$. Kadar enzim hepar SGOT $350 \mathrm{IU} / \mathrm{L}$ dan SGPT $285 \mathrm{IU} / \mathrm{L}$. Ureum $47 \mathrm{mg} / \mathrm{dL}$ dan kretinin $1,1 \mathrm{mg} /$ dL. Pemeriksaan urinalisis didapatkan protein +3, leukosit 10-12 /LPB, eritrosit 8-10/LPB. Hasil pemeriksaan rontgen thoraks didapatkan jantung dan paru tidak tampak kelainan. Pasien didiagnosis ASA 3 dengan eklampsia TD 180/110 
$\mathrm{mmHg}$ dan sindroma HELLP (trombositopenia $94.000 \mathrm{mg} / \mathrm{dL}$, SGOT $350 \mathrm{IU} / \mathrm{L}$ dan SGPT $285 \mathrm{IU} / \mathrm{L}$ ). Terapi yang diberikan $\mathrm{MgSO}_{4} 4 \mathrm{gr}$ intravena (IV) selama 20 menit dilanjutkan 1 gram/jam; ranitidin $50 \mathrm{mg} \mathrm{IV}$; deksametason $10 \mathrm{mg}$ IV; ceftriakson 1 gram IV. Tindakan anestesia yang dipilih pada pasien ini adalah dengan pembiuasan umum. Dilakukan informed consent mengenai rencana pembiusan beserta resiko-resiko yang dapat terjadi. Setelah mengerti dan setuju dengan rencana tindakan yang akan dilakukan, alat-alat dan obat untuk pembiusan umum dan emergency dipersiapkan, dilakukan pemasangan monitor untuk memantau tanda vital pasien selama operasi.

Pasien dalam posisi supine di atas meja operasi dilakukan preoksigenasi dengan oksigen 100\% selama 3 sampai 5 menit tanpa memberikan tekanan positif. Kemudian dilakukan penekanan krikoid, diberikan propofol $2 \mathrm{mg} / \mathrm{kg}$, fentanyl 2 $\mathrm{mcg} / \mathrm{kg}$, lidokain $1,5 \mathrm{mg} / \mathrm{kg}$ dan rokuronium 1,2 $\mathrm{mg} / \mathrm{kg}$ intravena. Setelah obat pelumpuh otot bekerja dilakukan intubasi. Intubasi menggunakan laringoskopi dengan pipa endotrakeal nomor 6,5 kemudian dihubungkan dengan circuit breathing dan dilakukan pemasangan pipa nasogastrik. Tindakan selanjutnya dilakukan setting ventilator dengan volume tidal $8 \mathrm{ml} / \mathrm{kg}$, RR $14 \mathrm{x} /$ menit, PEEP $5 \mathrm{cmH}_{2} \mathrm{O}, \mathrm{FiO}_{2}: \mathrm{N}_{2} \mathrm{O}=50 \%: 50 \%$. Dilakukan pemeliharaan dengan sevofluran 0,75 MAC dengan 1,5 volume \%. Setelah bayi dan plasenta lahir diberikan oksitosin drip 20 internasional unit (IU) dalam $500 \mathrm{ml}$ Ringer laktat (RL). Selama operasi berlangsung dilakukan monitoring hemodinamik. Operasi berjalan selama 30 menit, perdarahan selama operasi sekitar $1000 \mathrm{ml}$. Pasien kemudian dilakukan observasi di ICU untuk penanganan lebih lanjut.

Pasca operasi intubasi tetap dipertahankan dan disambung dengan ventilator. Ventilator disetting dengan pressure control $14 \mathrm{cmH}_{2} \mathrm{O}$, respiratory rate (RR) 12x/menit, PEEP $7 \mathrm{cmH}_{2} \mathrm{O}$ dan $\mathrm{FiO}_{2}$ $50 \%$. Pasien diberikan clear fluid melalui pipa nasogastrik dengan air putih $30 \mathrm{cc} / \mathrm{jam}$ dinaikkan bertahap sampai dengan makan cair serta posisi kepala head up 30o. Pasien diberikan analgetik morfin $1 \mathrm{mg} / \mathrm{jam}$ IV dan sedasi propofol $7 \mathrm{mg} /$ jam IV ditambah dengan midazolam $2 \mathrm{mg} / \mathrm{jam}$ IV. Pasien diberikan omeprazole $1 \times 40 \mathrm{mg}$ IV dan antibiotik diberikan ceftriakson $2 \times 1$ gr IV. Selama perawatan di ICU hari pertama hemodinamik dan kondisi pasien belum stabil dengan tekanan darah $160 / 100 \mathrm{mmHg}$ dan nadi $115 \mathrm{x} /$ menit serta diuresis $0,6 \mathrm{ml} / \mathrm{kg} / \mathrm{jam}$. Diberikan methyldopa 3x500 mg melalui pipa nasogastrik dan deksametasone 2x10 mg IV. Pada hari ke dua pasien dilakukan ekstubasi dan tetap dilakukan pemantauan hemodinamik dan diuresis.

Selama pemantauan hari kedua di ICU, didapatkan kesadaran pasien kompos mentis dan tanda vital pasien relatif stabil dengan $\mathrm{SpO}_{2}$ 98$100 \%$ oksigen nasal kanul $4 \mathrm{~L} /$ menit, tekanan darah 140/90 mmHg, frekuensi nadi 100x/menit dan RR 20x/menit. Diuresis selama 24 jam didapatkan sekitar $0,8 \mathrm{ml} / \mathrm{kg} / \mathrm{jam}$ dengan warna urin sudah mulai kuning. Balanced cairan harian didapatkan positif $800 \mathrm{ml}$. Hasil laboratorium post operasi hemoglobin $11 \mathrm{gr} \%$, hematocrit $32 \%$, leukosit $25.500 \mathrm{mg} / \mathrm{dL}$, trombosit 120.000 $\mathrm{mg} / \mathrm{dL}$, GDS $115 \mathrm{mg} / \mathrm{dL}$. Kadar enzim hepar SGOT 345 IU/L dan SGPT 290 IU/L. Ureum 50 $\mathrm{mg} / \mathrm{dL}$ dan kretinin $2,8 \mathrm{mg} / \mathrm{dL}$.

\section{Pembahasan}

Sindroma HELLP yang ditandai dengan adanya hemolysis, peningkatan enzim hepar dan trombositopenia. Sindroma ini merupakan salah satu bentuk dari preeclampsia. Berkaitan dengan meningkatnya morbiditas maternal termasuk DIC, abrupsio plasenta, edema paru, gagal ginjal akut perdarahan hepar, distress respirasi akut, sepsis, stroke dan kematian. ${ }^{11}$ Onset sindroma HELLP terjadi pada masa antepartum pada $70 \%$ kasus dan post partum pada 30\% kasus.

Hemolysis didefinisikan sebagai adanya anemia hemolitik mikroangiopatik merupakan penanda klasik dari pasien sindroma HELLP. Pada pemeriksaan darah tepi didapatkan schistosit, sel Burr dan echinosit. ${ }^{12}$ Standar kriteria diagnosis dari pemeriksaan laboratorium yang diusulkan oleh Sibai, antara lain adalah hemolisis (tergambarkan dengan hapusan darah tepi yang abnormal, peningkatan bilirubin $>1,2 \mathrm{mg} / \mathrm{dL}$ 
dan peningkatan $\mathrm{LDH}>600 \mathrm{IU} / \mathrm{L})$, Peningkatan enzim hati (SGOT $\geq 70 \mathrm{IU} / \mathrm{L}$, peningkatan LDH $>600 \mathrm{IU} / \mathrm{L}$ ) dan trombositopenia (jumlah trombosit $<100.000 / \mathrm{mm} 3){ }^{12}$

Pada kasus ini diagnosis sindroma HELLP ditegakan sesuai dengan kriteria diagnosis antara lain peningkatan enzim hepar SGOT $350 \mathrm{IU} / \mathrm{L}$, SGPT $285 \mathrm{IU} / \mathrm{L}$ dan trombositopenia $94.000 \mathrm{mg} / \mathrm{dL}$. Kadar bilirubin pada pasien ini tidak diperiksa, namun dari pemeriksaan fisik didapatkan sklera yang ikterik pada mata yang dapat menggambarkan bilirubin yang tinggi di dalam darah. Apabila tidak semua kriteria sindroma HELLP didapatkan dapat disebut sindroma HELLP parsial. Jumlah penurunan trombosit perlu mendapatkan perhatian tersendiri sebelum dilakukan tindakan anesthesia. Pada pasien dengan jumlah trombosit kurang dari $50.000 \mathrm{mg} / \mathrm{dL}$ memiliki resiko yang signifikan terjadinya perdarahan. ${ }^{13}$

Sehingga pada kondisi tersebut anestesia umum merupakan anestesia pilihan. Pada pasien ini didapatkan trombositopenia $94.000 \mathrm{mg} / \mathrm{dL}$ serta kondisi eklamsia yang menyertainya, maka dipilih anestesia umum untuk memfasilitasi tindakan seksio sesarea. Anestesia umum menjadi pilihan dikarenakan untuk mengurangi komplikasi perdarahan neuraksial serta menjaga kondisi ibu (sistem saraf pusat/otak) yang sudah mengalami kejang sebanyak 2 kali. Studi menunjukkan bahwa pemberian deksametason akan memperbaiki jumlah trombosit pada pasien sindroma HELLP. ${ }^{14}$ Pada kasus ini pasien mendapatkan terapi deksametason $2 \times 10 \mathrm{mg}$ IV untuk hari pertama dan kedua serta $2 \times 5 m g$ IV untuk hari ketiga dan keempat. Transfusi trombosit diindikasikan pada adanya perdarahan yang signifikan dengan jumlah trombosit kurang dari $20.000 / \mathrm{mm} 3$. Pada wanita dengan trombositopenia kurang dari 40.000/mm3 disarankan dilakukan transfusi minimal 2 unit sebelum dilakukan prosedur seksio sesarea. ${ }^{15}$

Gejala nyeri abdomen daerah kanan atas yang disertai dengan mual dan muntah serta sakit kepala merupakan sebuah tanda kemungkinan adanya ruptur hematoma subkapsular hepar yang merupakan salah satu komplikasi yang mungkin terjadi pada sindroma HELLP dan preeklampsia berat (PEB). ${ }^{16}$ Diagnosis dikonfirmasi melalui pemeriksaan USG, CT scan maupun MRI. Pada kondisi yang disertai dengan syok diperlukan tindakan pembedahan segera. ${ }^{17}$ Pada kondisi dimana keadaan hemodinamik pasien stabil, maka pendekatan yang dilakukan adalah manajemen konservatif dengan melakukan evaluasi dan monitoring melalui ultrasonografi, CT scan maupun MRI. Selain itu pada manajemen konservatif ini diperlukan pencegahan terjadinya trauma pada hepar seperti kejang, muntah dan palpasi abdomen. Pada saat memindahkan pasien juga harus dengan cara yang hati-hati untuk menghindari ruptur hematoma. Pada kasus ini, pasien mengeluh nyeri abdomen pada kuadran kanan atas, namun setelah dilakukan pemeriksaan penunjang ultrasonografi tidak ditemukan adanya ruptur hematoma subkapsuler hepar. Manajemen anestesia pada pasien dengan preeklampsia berbeda dengan pasien tanpa preeklampsia. Manajemen anestesia pada preeklampsia dengan penyulit perlu dipertimbangkan kondisi dan progresi tingkat berat ringannya penyulit serta kesiapannya untuk dilakukan seksio sesarea segera. ${ }^{18}$ Penilaian sebelum dilakukan anestesia pada pasien dengan preeklampsia harus fokus pada jalan nafas, hemodinamik maternal, status koagulasi dan keseimbangan cairan. Keadaan edema generalisata dapat mempengaruhi jalan nafas dan menghalangi padangan penanda anatomi pada visualisasi dengan laringoskop. Sehingga dokter anestesi perlu mempersiapkan bagaimana manajemen jalan nafas yang sulit.

Pada kasus ini pasien dilakukan pembiusan umum yang memiliki risiko kemungkinan pasien sulit dilakukan intubasi mengingat adanya kemungkinan edema pada jalan nafas dan adanya resiko peningkatan tekanan intrakranial ketika intubasi dan ekstubasi. Beberapa indikasi dilakukan pembiusan umum adalah adanya perdarahan maternal yang sedang berlangsung, bradikardia pada janin, trombositopenia berat atau adanya gangguan koagulasi atau kombinasi ketiganya. ${ }^{18}$ Sindroma HELLP yang disertai dengan eklamsia yang terjadi pada kasus ini juga merupakan indikasi dilakukan pembiusan umum. Ketika pembiusan umum dilakukan pada pasien dengan preeklampsia diperlukan beberapa 
persiapan yang cukup. Tiga tantangan spesifik yang perlu diperhatikan adalah adanya kemungkinan akses jalan nafas yang sulit, respon hipertensif pada pemasangan laringoskop dan intubasi serta efek magnesium sulfat pada transmisi neuromuskular yang akan mempengaruhi kontraksi uterus. ${ }^{19}$ Kemungkinan kesulitan intubasi pada kasus ini dicegah dengan dilakukannya Sellickmaneuver dengan penekanan krikoid untuk mempermudah tindakan intubasi dan visualisasi pemasangan pipa endotrakeal serta menghindari percobaan pemasangan yang berulang karena dapat mengakibatkan trauma jalan nafas. Hipertensi yang berat dapat dicegah dengan melakukan monitoring tekanan darah secara terus menerus serta menjaga tekanan darah selama intubasi dengan tekanan sistolik 140 hingga $160 \mathrm{mmHg}$ dan diastolik antara 90 hingga 100 mmHg. ${ }^{20-24}$ Sebelum dilakukan intubasi pada pasien ini diberikan analgetik fentanyl serta lidokain $1,5 \mathrm{mg} / \mathrm{kg}$ IV untuk menumpulkan respon hemodinamik selama dilakukan intubasi. Tekanan darah ketika dilakukan intubasi adalah 145/98 mmHg, sehingga kemungkinan terjadinya peningkatan tekanan darah tinggi yang dapat mengakibatkan peningkatan tekanan intrakranial dapat dihindari. Pilihan analgesia post operatif pada pasien seksio sesarea sama dengan persalinan normal pervaginam. Menurut ACOG, pasien post partum dengan hipertensi yang menetap lebih dari satu hari disarankan untuk tidak menggunakan analgetik anti inflamasi non steroid karena dapat mengakibatkan hipertensi. ${ }^{25}$ Namun demikian disarankan pemakaian analgetik jenis opioid pada pasien perlu dilakukan monitoring dengan pulse oksimetri untuk melihat adanya tanda-tanda depresi nafas.

\section{Simpulan}

Sindroma HELLP dan eklampsia merupakan bentuk perburukan dari preeklampsia yang dapat mengakibatkan peningkatan morbiditas dan mortalitas ibu. Manajemen dan tatalaksana keduanya berupa suportif serta terapi definitif adalah dengan melahirkan bayi dan plasenta. Sindroma HELLP pada umumnya terjadi pada usia kehamilan 27 hingga 37 minggu, namun demikian pada kasus ini didapatkan pada usia kehamilan yang lebih awal yaitu 24 minggu. Walaupun patofisiologi sindroma HELLP dan preeklampsia hingga saat ini masih belum jelas, namun pengenalan secara dini tanda dan gejala awal merupakan kunci untuk menghindari prognosis yang lebih buruk hingga kematian bagi ibu. Melalui pemahaman ini, manajemen anestesia yang berbasis pemahaman akan patofisiologi preeklampsia merupakan hal mutlak yang diperlukan agar morbiditas dan mortalitas dapat diminimalkan.

\section{Daftar Pustaka}

1. Tranquilli AL, Dekker G, Magee L, Roberts J, Sibai BM, Steyn W, et al. The classification, diagnosis and management of the hypertensive disorders of pregnancy: A revised statement from the ISSHP. Pregnancy Hypertens. 2014;4(2):97-104.

2. Task Force on Hypertension in Pregnancy. Hypertension in Pregnancy Guideline. American College of Obstetricians and Gynecologists; 2014.

3. Magee LA, Pels A, Helewa M, Rey E, von Dadelszen P, Canadian Hypertensive Disorders of Pregnancy Working G, et al. The hypertensive disorders of pregnancy. Best Pract Res Clin Obstet Gynaecol. 2015;29(5):643-57.

4. Cunningham FG and Gant N. "William Obstetrics" 24th ed. McGraw-Hill, Medical Publishing Division, 2014; 706-56.

5. Dilmy MA and Purwosunu Y. Prevalence and characteristics of hypertensive disorder in pregnancy at Cipto Mangunkusumo National General Hospital in 2016. Indonesian J. Obstet. gynecol. 2017;12: 35-37.

6. Hypertension Guideline Committee; Strategic Training Initiative in Research in The Reproductive Health Sciences (STIRRHS) Scholars. Diagnosis, evaluation and management of the hypertensive disorders of pregnancy. J Obstet Gynaecol 
Can. 2008;30(3).

7. RCOG. Green Top Guideline: The management of pre-eclampsia/eclampsia. Royal College of Obstetricians and Gynaecologists. Guideline no 10 (A), 2006.

8. L. Weinstein, Syndrome of hemolysis, elevated liver enzymes, and low platelet count: a severe consequence of hypertension in pregnancy, Am. J. Obstet. Gynecol. 142 (1982) 159-167.

9. L. Weinstein, Preeklampsia/eclampsia with hemolysis, elevated liver enzymes, and thrombocytopenia, Obstet. Gynecol. 66 (1985) 657-660.

10. A.K. Ertan, S. Wagner, H.J. Hendrik, H.A. Tanriverdi, W. Schmidt, Clinical and biophysical aspects of HELLP-syndrome, J. Perinat. Med. 30 (2002) 483-489.

11. B.M. Sibai, M.K. Ramadan, I. Usta, M. Salama, B.M. Mercer, S.A. Friedman, Maternal morbidity andmortality in 442 pregnancies with hemolysis, elevated liver enzymes, and low platelets (HELLP syndrome), Am. J. Obstet. Gynecol. 169 (1993) 1000-1006.

12. Sibai BM. Diagnosis, controversies, and management of the syndrome of hemolysis, elevated liver enzymes, and low platelet count. Obstet Gynecol 2004; 103:981-91.

13. Douglas M. The use of neuraxial anesthesia in parturients with thrombocytopenia: what is an adequate platelet count? In Halpern S, Douglas M, editors. Evidence-Based Obstetric Anaesthesia. Oxford, Blackwell Publishing, 2005:165-77.

14. Woudstra DM, Chandra S, Hofmeyr GJ, Dowswell T. Corticosteroids for HELLP (hemolysis, elevated liver enzymes, low platelets) syndrome in pregnancy. Cochrane Database Syst Rev 2010; (9):CD008148.
15. Barton J, Sibai B. Diagnosis and management of hemolysis, elevated liver enzymes, and low platelets syndrome. Clin Perinatol 2004; 31:807-33.

16. Vigil-De Gracia P, Ortega-Paz L. Preeclampsia/eclampsia and hepatic rupture. Int J Gynaecol Obstet 2012; 118:186-9.

17. Sheikh RA, Yasmeen S, Pauly MP, Riegler JL. Spontaneous intrahepatic hemorrhage and hepatic rupture in the HELLP syndrome: four cases and a review. J Clin Gastroenterol $1999 ; 28: 323-8$.

18. Bateman BT and Polley LS. Hypertensive Disorders. In: Chestnuts DH, Wong CA, Tsen LC, Ngan Kee WD, Beilin Y, Mhyre JM, editors. Chestnut's Obstetric Anesthesia Principles and Practice, 5th ed. Philadelphia: Elsevier Saunders, 2014. 915-31.

19. Ramanathan J, Bennett K. Pre-eclampsia: fluids, drugs, and anesthetic management. Anesthesiol Clin North Am 2003; 21:145-63.

20. Stempel JE, O'Grady JP, Morton MJ, Johnson KA. Use of sodium nitroprusside in complications of gestational hypertension. Obstet Gynecol 1982; 60:533-8.

21. Hood DD, Dewan DM, James FM 3rd. The use of nitroglycerin in preventing the hypertensive response to tracheal intubation in severe preeklampsia. Anesthesiology 1985; 63:329-32.

22. Ramanathan J, Sibai BM, Mabie WC. The use of labetalol for attenuation of the hypertensive response to endotracheal intubation in preeklampsia. Am J Obstet Gynecol 1988; 159:650-4.

23. Baker AB. Management of severe pregnancyinduced hypertension, or gestosis, with sodium nitroprusside. Anaesth Intensive Care 1990; 18:361-5.

24. Ngan Kee WD, Khaw KS, Ma KC. Maternal 
and neonatal effects of remifentanil at induction of general anesthesia for cesarean delivery: a randomized, double-blind, controlled trial. Anesthesiology 2006; 104:14-20.
25. American College of Obstetricians and Gynecologists Taskforce on Hypertension in Pregnancy. Hypertension in pregnancy. ACOG. Washington, DC, 2013. 